\title{
ІДЕЇ ЖІНОЧОЇ ЕМАНСИПАЦЇ̈ В ЛІТЕРАТУРНО-КРИТИЧНІЙ ТВОРЧОСТІ ЕЛІЗИ ОЖЕШКО І НАТАЛІЇ КОБРИНСЬКОЇ
}

\author{
Ірина Спатар
}

Кандидат філологічних наук, викладач,

Кафедра світової літератури і порівняльного літературознавства, Прикарпатський національний університет імені Василя Стефаника (УКРАЇНА), 76018, м. Івано-Франківськ, вул. Шевченка, 57, e-mail: irynaspatar@ukr.net

\section{РЕФЕРАТ}

Mema. Стаття присвячена дослідженню особливостей інтерпретації емансипаційного дискурсу Е. Ожешко й Н. Кобринської, з постатями яких у польському та українському письменствах пов'язують зародження і розвиток феміністичного світогляду. Мета - 3’ясувати типологічно подібні й індивідуально авторські постулювання емансипаційних ідей в літературно-публіцистичному доробку письменниць. Дослідницька методика. Для зіставного аналізу застосовано низку основних методів наукового дослідження, зокрема історико-літературний, типологічний, біографічний підходи. Результати. Здійснено спробу порівняльного аналізу художнього декларування паритетності статей крізь призму ранньої творчості обох письменниць. Окреслено авторське бачення особливої функції жінки в соціальному, духовноінтелектуальному, національному контекстах. Наукова новизна. У запропонованій роботі вперше шляхом компаративного зіставлення досліджено типологічні паралелі ідей жіночої емансипації в доробку Е. Ожешко та О. Кобилянської. Практичне значення. Основні результати дослідження можуть бути використані при подальшому вивченні польського та українського літературних процесів другої половини XIX - початку XX століття, а також творчості Е. Ожешко і Н. Кобринської.

Ключові слова: емансипація, публіцистично-літературний дискурс, гендерна паритетність, жіноче питання.

\section{THE IDEA OF THE FEMALE EMANCIPATION IN THE LITERARY AND CRITICAL WORKS BY ELIZA ORZESZKOWA AND NATALIIA KOBRYNSKA}

\section{Iryna Spatar}

\author{
$\mathrm{Ph}$. D. in Philology, Lecturer, \\ Department of World Literature and Comparative Literary Criticism, \\ Vasyl Stefanyk Precarpathian National University (UKRAINE), \\ 76018, Ivano-Frankivsk, 57, Shevchenko str., \\ e-mail: irynaspatar@ukr.net
}

\begin{abstract}
Aim. The article deals with the research of the peculiarities of interpretation of emancipation discourse by E. Orzeszkowa and N. Kobrynska, whose personalities are associated with the formationThe purpose of the article is to investigate typologically similar and the author's personal postulations of the emancipation ideas in the literary and publicist works by the writers. Methods. The comparative analysis draws a range of basic methods of scientific research, namely historical and literary, typological and biographical approaches. Results. An attempt was made to compare the artistic declaration of the parity of the sexes through the prism of the early works by both writers. The authors' vision of a special function of a woman in social, spiritual and intellectual, national contexts is outlined. Scientific novelty. In the article there has been made the investigation of the typological parallels of the ideas of female emancipation in the works of E. Ozheshko and O. Kobylianska by means comparative analysis, for the first time. Practical meaning. Main results of the research can be used in further
\end{abstract}


study of the Polish an Ukrainian literary process of the second half of the $19^{\text {th }}-$ beginning of the $20^{\text {th }}$ century and of E. Orzeszkowa's and N. Kobrynska's works.

Key words: emancipation, publicist and literary discourse, gender parity, women's issue.

Еліза Ожешко і Наталія Кобринська - це ключові постаті, з іменами яких пов'язані витоки емансипаційного дискурсу в польському та українському історико-культурному, мистецькому, літературознавчому контекстах. Осмислення місця та ролі жінки в суспільстві, державі, літературі, а також відстоювання рівноправних умов щодо праці, освіти, громадської діяльності були не лише предметом публіцистичних теоретизувань і художнього оприявнення у текстах, але й чіткою громадянською позицією, домінантним життєвим кредо обох письменниць. Вони стали апологетами «жіночої квестії» у різних національних середовищах, очоливши спільний шлях «нового суспільного руху, зорієнтованого передусім на формування національно свідомого, духовно розкріпаченого й інтелектуально розвинутого жіноцтва» [8, с. 183].

Взявши за основу компаративну спрямованість даної статті, зосереджуємо увагу на критично-літературних рефлексіях раннього періоду творчості Е. Ожешко («Кілька слів про жінок», «Марта») й Н. Кобринської (критичні публікації авторки у «Першому вінку» і перші прозові твори «Задля кусника хліба», «Дух часу»). Такий вибір зумовлений потребою з'ясувати типологічно подібні й індивідуально авторські постулювання емансипаційних ідей у доробку письменниць, з постатями яких у польському та українському письменствах пов'язують зародження і розвиток феміністичного світогляду.

Процеси духовно-інтелектуального становлення і поступової кристалізації емансипаційних переконань Е. Ожешко та Н. Кобринської відбувалися у схожих умовах. 3 дитячих років вони виховувалися серед книжок, любов до яких кожній прививав насамперед батько - адвокат Бенедикт Павловський та священик Іван Озаркевич. Майбутні письменниці володіли іноземними мовами (польською і німецькою Н. Кобринська, французькою Е. Ожешко), багато читали художніх та філософських текстів, критичних розвідок, у яких йшлося про зміни до усталених патріархальних кліше, а жінці пропонувалися нові соціально-культурні ролі. Перманентна, особлива внутрішня потреба знань, різностороннього поступу стали грунтом для підсвідомого формування у молодих авторок культу самоосвіти, безперервного альтруїзму і боротьби на різних рівнях: соціальному, духовно-ментальному, патріотичному, ідеологічному, зокрема феміністичному через пропагування емансипаційних ідей.

На польських землях емансипаційний рух активізувався у 70-х роках XIX століття, проте значно раніше Климентина з Танських Гоффманова висловила міркування про необхідність нових підходів до виховання та освіти жінок у романі «Згадка про добру Матір чи іiі останні поради для доньки» ${ }^{1}$ (Рamiątka po dobrej matce, czyli ostatnie jej rady dla córki. Przez młodą Polkę, 1819). У своїх

\footnotetext{
${ }^{1}$ Тут і далі переклад з польської наш (I. C.).
} 
працях ${ }^{2}$ К. Гоффманова репрезентувала новий тип жінки: освіченої, суспільно заангажованої, яка $є$ патріоткою і глибоко віруючою людиною. Однак радикальних змін, спрямованих на боротьбу за паритетність статей, у ії̈ поглядах немає, авторка визнавала «другорядну роль жінки у публічному житті та необхідність підпорядкування ії чоловікові» [9, с. 104]. К. Гоффманова була однією 3 перших польських літераторок, що заробляла на життя художнім словом, а іiі творчість стала способом трансляції нових поглядів про необхідність виховання у дівчат самостійності і патріотичної свідомості. Питання про рівноправність та форматування патріархальних стереотипів крізь призму літературних і публіцистичних праць продовжувала декларувати учениця К. Гоффманової - письменниця Нарциза Жміховська - лідерка польських «Ентузіасток» ${ }^{3}$. Е. Ожешко була добре обізнана 3 діяльністю землячок, що заклали підвалини подальшого емансипаційного подвижництва. Проте складні суспільно-політичні та історико-культурні події, які характеризувалися втратою держави, тотальною русифікацією і германізацією, невдалою спробою боротьби за незалежність, економічним занепадом, впливали на формування феміністичної свідомості, емансипаційних постулатів і дій. Концептуально проголошення жіночої свободи відрізнялося від західної моделі відстоювання гендерної рівності. У слов'янському контексті особливе місце відводилося національній складовій, зокрема реалізації патріотичних завдань та утилітарних принципів програми позитивізму. Польський критик Т. Яске-Хоінський стверджував: «Якби раптовий економічний переворот після 1863 року не викинув у нашому краї кілька тисяч жінок <...> 3 усталених традицією доріг і не змусив їх до самостійної боротьби за виживання, за право на життя, ми не мали б так званої емансипації. Допоміг їй наш позитивізм, iіi усердний речник, що посилив свою позицію еволюційною доктриною» [3, с. 6]. Праці французьких та англійських позитивістів (О. Комта, Г. Спенсера, I. Тена, Е. Ренана, Дж. С. Мілля) були дуже популярними в інтелектуальних колах. Взявши за основу філософські вчення згаданих мислителів, польські письменники формулювали літературні маніфести (стаття «Ми і Ви» А. Свєнтоховського) та друкували художні твори (Болеслав Прус), у яких пропагували ідеї позитивізму, зокрема гасло емансипації. У другій половині XIX століття тема жіночої недолі стала однією 3 найпопулярніших у прозових полотнах.

Найбільш палкою прихильницею жіночого питання у польському красному письменстві того часу була Е. Ожешко. У літературно-критичному дискурсі письменниці експліковано емансипаційну проблематику та виписано палітру жіночих образів на тлі складної суспільно-психологічної ситуації доби. Великого розголосу, критики і схвалень отримала публіцистична розвідка, за жанровими ознаками більше схожа до есе, «Кілька слів про жінок», що друку-

\footnotetext{
2 Окрім згаданого роману, К. Гоффманова пропонувала нові принципи виховання дівчат у таких творах, як «Listy matki o wychowaniu córek swoich» (1822-1826), «Amelia matką. Dzieło za dalszy ciąg „Pamiątki po dobrej matce" służyć mogące, przez tęż samą Autorkę» (1822-1824), та статтi «O powinnościach kobiet» (1849).

3 Варшавське літературне угрупування, діяльність якого тривала протягом 1842-1848 років. Назва «Ентузіастки» закріпилася 31876 року. Ї̈ запропонувала Н. Жміховська, характеризуючи групу жінок, які, починаючи з 40-х років, пропагували емансипаційні погляди.
} 
валася на шпальтах варшавського часопису «Тижневик Мод» (№ 40-50) у 1870 році. Скрупульозний аналіз статусу і місця жінки у суспільстві, іiі обов'язки як дружини і матері, від яких залежить доля держави, а також зміна пріоритетів у вихованні та навчанні жінок, необхідність освоювати ремісничі професії не лише чоловікам, паритетність статей щодо праці та освіти - це домінантні аспекти статті, яку авторка структурувала трьома частинами («Про цілі та шляхи жінок», «Про виховання жінок», «Про працю жінок»). Основним життєвим принципом кожної жінки має стати безперервна робота над собою, розширення і поглиблення інтелектуально-естетичних горизонтів, ерудиції. «Хто не здійснює поступу, той деградує і людина повинна удосконалювати себе протягом усього життя» [6, с. 169] - це дві надважливі домінанти, на думку польської авторки, керуючись якими можна подолати соціально-політичну і суспільнодуховну кризи.

У 1873 році на сторінках «Тижневика Мод» Е. Ожешко запропонувала художню версію інтерпретації емансипаційної проблематики у романі «Марта». Конотаційний вектор твору, який у польському літературознавчому просторі марковано як «перший польський феміністичний роман» [5, с. 413], кореспондує 3 концепцією публіцистичної розвідки «Кілька слів про жінок». Літературна рефлексія авторки, що позиціонувала неемансиповану жінку як приклад суспільної і національної трагедії, отримала неабиякий резонанс, «статус бестселера» [5, с. 413] не лише в національному середовищі, але й у світі. Образ Марти, молодої вдови, став безапеляційним аргументом того, що жінка, позбавлена зі сторони сильної половини опіки і матеріальної підтримки (батька, чоловіка, коханця / покровителя), немає грунтовної освіти та відповідних професійних навичок і вмінь, приречена на поневіряння, жебрацтво, фатальний життєвий фінал. Становище, у якому опинилася героїня після смерті чоловіка, виявилося для Марти безвихідним. Відсутність годувальника сім’ї стала початком краху двох доль: непристосованої до самостійного буття жінки і їі маленької донечки. Раптова зміна умов (втрата комфортного, теплого житла, погане харчування) негативно вплинула на здоров'я дівчинки, яка була жертвою обставин, й остаточно зруйнувала безтурботне, щасливе дитинство. Піврічний пошук заробітку щоразу приносив Марті лише розчарування і усвідомлення того, що вона абсолютно не здатна протистояти жорстокій дійсності: «Ніщо не озброїло мене проти убогості, ніщо не навчило праці» [7, с. 103].

У романі «Марта» експліковано письменницьку візію таких ключових питань емансипаційного руху, як необхідність інтелектуального поступу i прикладної суспільної заангажованості жінок. Устами героїні Е. Ожешко оскаржує «салонні знання», які варто трактувати як деструктивну складову фемінної екзистенції. Вони не свідчать про ерудицію представниць середнього класу, а навпаки можуть стати каменем спотикання у звичайних реаліях. Тому обов'язково змінювати методику виховання і навчання дівчат. «Чому люди вимагають від мене того, чого мені ніхто не дав? Чому мені ніхто не дав того, чого сьогодні від мене вимагають люди?» [7, с. 116] у розпачі формулює риторичні питання Марта. Іншою причиною фатальної перспективи жіночого буття $\epsilon$ відсутність гендерного паритету. 
Пошуки роботи і намагання працювати в найрізноманітніших сферах виявилися марними для молодої героїні. Вона стала заручницею суспільноментальних стереотипів, до боротьби з якими була не спроможна фізично і не готова психологічно. Марта не змогла конкурувати на ринку праці через те, що iï знання надто поверхові, крім того, багато галузей, де можна працювати, це «маскулінна територія». Саме через стать героїні відмовлено у таких посадах, як продавець тканин і одягу («... у нашому магазині жінки ніколи не продають товарів, лише чоловіки... Але чому жінки не роблять того, що чоловіки? <...> тому, що така вже традиція» [7, с. 98-99]), ілюстратор у редакції, проектант біжутерії («Але ж, пані добродійко! Пані добродійка є жінкою! <...> Я жінка, це правда. I що з того?» [7, с. 220]). Проте звільніти ії від верховенства штучно увіковічених стереотипів надто складно. Почувши про бажання Марти малювати ескізи прикрас, чоловіки «зі здивуванням й іронією» [7, с. 217] дивилися на молоду жінку, а власник-ювелір дав зрозуміти молодій вдові, що він не готовий і не хоче бути емансипаційним реформатором: «Признаюся, я недуже люблю всякі новинки» [7, с. 220]. У романі Е. Ожешко увиразнила низку провідних тенденцій емансипаційного руху: для того, щоб побороти усталені патріархальні норми, потрібно змінити суспільну свідомість, уможливити жінці доступ до університетів, усестороннього розвитку, а не виховувати 3 неї ляльку чи прикрасу, тінь чоловіка.

Досвід перших польських феміністок підштовхнув Н. Кобринську до ширшого студіювання жіночого питання, адаптації європейського емансипаційної практики до національних і регіональних умов та подальшої кристалізації індивідуальних версій i шляхів актуалізації феміністичних переконань. Рецепція нової концепції, пов'язаної з активізацію жіночого руху, посилила «цікавість щодо личних відносин жінок і мужчин» [4, с. 317]. У домашній бібліотеці батька українська письменниця «знайшла раз невеличку польську книжку, котра $<\ldots>$ оказалася дуже цінним набутком. В тій книжці подибала я рецензію якоїсь французької розвідки, в котрій автор обурювався на те, що жінки ставляться нижче мужчин, і старався доказати, що оба поли суть собі рівні, а хоть і різняться між собою деякими прикметами, то власне, тим доповнюються [4, с. 316]. Увагу галицької авторки також привернула низка художніх і критичних праць К. Гоффманової. Сервілістичні роздуми польської мислительки були сприйняті Н. Кобринською неоднозначно: «...вічне представлення висоти жінки тим, що завше ліпше триматися жінці утертих шляхів, як рватися на якісь нові дороги життя, - дражнили і упокорювали мене. Все ж вона зробила стільки, що я пішла ії шляхами і почала-м старатися усіма силами піддатися iї провідним думкам» [4, с. 317]. Н. Кобринській імпонувала «та талановита писателька» [4, с. 309] хоча б через те, що К. Гоффманова однією 3 перших у власному літературно-критичному доробку звернула увагу на жінку як особистість, патріотку, яка $є$ відповідальною за виховання християнських чеснот, а також особистим прикладом показала можливість реалізації на літературній ниві. Українська письменниця визнала, що «польська генерація жінок завдячувала Гоффмановій своїм національним розвитком» [цит. за: 8, с. 186], однак іiі розуміння емансипаційних поглядів суперечило позиції польської 
авторки, яка, на думку Н. Кобринської, «остро ганила найменші об'яви самостійності в жінці» [4, с. 309]. Близькими для молодої галичанки були біблійні настанови щодо упокорення жінки перед чоловіком, якими послуговувалася К. Гоффманова: «Творець призначив чоловіків для правління і старшинства», а жінок до «покори» і «послуху» [цит. за: 9, с. 109]. Донька священика також резюмувала: «Сам Бог казав, що жінка має бути підданкою свого мужа, інакше понимати сі відносини значило те саме, що виступати проти Бога i релігії» [4, с. 317]. Однак «ексцентрично релігійна» [4, с. 317] Н. Кобринська незабаром скорегувала аксіологічні орієнтири під впливом нових філософських вчень позитивізму, що охопили Європу в другій половині XIX століття. Науково-емпіричний підхід до тлумачення усіх явищ та процесів, що відбуваються у середовищі, історії, культурі став для майбутньої письменниці проекцією суспільно-ідейних та мистецьких пошуків і проектів.

Духовно-інтелектуальна еволюція світогляду галицької феміністки, зумовлена впливом школи позитивізму, спонукала до переосмислення релігійних догм та морально-етичних категорій ортодоксальної релігійної доктрини: «Твори тої школи почали руйнувати не лише мої релігійні виображення, але також і погляди на життя і на той суспільний лад, який мене окружав» $[4$, с. 318]. Кульмінаційним моментом у формуванні «феміністичної свідомості» [4, c. 187] Н. Кобринської стала розвідка англійського філософа С. Мілля «Поневолення жінок», 1869. Письменниця ознайомилася з німецькою версією й настільки захопилася ідеями вченого, що мала на меті здійснити переклад рідною мовою. У цій фундаментальній праці молода галичанка знаходила чіткі формулювання нових для неї положень, які були суголосними до ії міркувань, а також розширювали горизонти ерудиції та доповнювали науковий сегмент знань: «мої декуди темні і необ'яснені думки об'яснялись одною 3 перших наукових поваг; то мені надавало певності і сили» [4, с. 320].

Джерелом позитивістської лектури, у якій опрявнювалися емансипаційні гасла, була також польська белетристика, зокрема твори Е. Ожешко. Н. Кобринська схвально оцінювала прозопис авторки «Марти», але публіцистична розвідка, присвячена жіночій квестії, не підкорила ії викінченого під впливом сконкретизованих тез Дж. С. Мілля феміністичного фокусу. «Якось зараз по тім дісталася мені була в руки книжка «Kilka słów o kobietach» Ожешкової - то та високо тепер цінена мною писателька яко повістярка видалася мені насупроти Штуарта Мілля слабою і неконсеквентною» [4, с. 320]. Варто зазначити, що згадана праця Е. Ожешко була опублікована у 1879 році. Саме тоді з'явився польськомовний переклад «Поневолення жінок». У польському літературознавстві існує думка, що «задум і план розвідки авторка мала вже у 1867» [5, c. 415], тобто ідейно-проблематичний спектр своєї праці письменниця обмірковувала не один рік, одночасно спостерігаючи і вивчаючи найгостріші суспільно-історичні невдачі свого народу, шукаючи і пропонуючи шляхи поступу для конкретних національних реалій. Англійський філософ «постулював звільнення залежності жінок, ув'язнених звичаєм і традицією, від чоловіків і основним для нього (С. Мілля. - I. C.) було питання цивілізаційного поступу» $[5$, c. 414]. Висловлюючи судження про обов'язкові зміни щодо рівноправності 
статей, Е. Ожешко оперлася на соціально-національний контекст. Тому пропоновані рекомендації спрямовувала насамперед до землячок, яким потрібно допомогти зорієнтуватися у нових підходах до виховання і навчання жінки, щоб вижити фізично та на паритетних засадах долучитися до подальших історико-культурних, інтелектуально-економічних зрушень: «Десь-інде це питання вже абсолютно вирішене, як в Сполучених Штатах або дуже близьке до остаточного вирішення, як в Англії, Франції чи Німеччині» [6, с. 167.] Основна функція статті «Кілька слів про жінок» полягала у практичному втіленні зазначених теоретичних ідей (грунтовна освіта, виховання самостійності, освоєння ремесел, фізична активність, науково-практична діяльність жінок). У даному контексті варто звернутися до думки української дослідниці А. Швець, яка, науково обгрунтувавши роль Н. Кобринської у творенні національного варіанту фемінізму, влучно зауважила, що програми жіночого руху суттєво вирізняли його від модерного європейського фемінізму конкретними утилітарними, філантропічними й просвітницькими завданнями [8, с. 196].

Пильне студіювання та безперервне читання Н. Кобринською найрізноманітніших текстів сфокусували емансипаційні інтенції письменниці у простір власного публіцистично-художнього дискурсу. В «Автобіографії» авторка резюмувала: «Я через літературу дійшла до розуміння положення жінки в суспільності - тож хотіла-м і других повести на ту дорогу» [4, с. 322]. Іманентне прагнення змінити патріархальні умонастрої доби реалізувала також у громадській діяльності - заснувала жіночий рух в Галичині, зокрема очолила «Товариство руських женщин». Найбільш органічною сферою екзистенції письменниці була словесна практика. Публіцистичними розвідками продовжувала «розбудовувати теоретико-історичний дискурс українського жіночого руху» [4, с. 188], а у художній творчості майстерно відтворювала «дух часу».

У розвідці «Руське жіноцтво в Галичині в наших часах» Н. Кобринська вказала нелегке життя представниць кількох суспільних прошарків, згадавши селянок, «середню верству» і аристократок. Диференційний спектр діяльності цих різних жінок мав свої особливості, однак спільним фактором, що стосувався фемінної частини статі і вимагав негайних змін, було питання освіти. «Просвіта селянки дуже низька. <..> найчастіше, відбувши свою шкільну науку, ніколи вже не заглядають до книжки і швидко забувають ті початки, яких в школі навчилися» [4, с. 304]. Проблему жінок середнього класу авторка зауважує у способі виховання («Тут жінка майже вповні залежить від заробітку мужчини» [4, с. 314]) та проекцією майбутньої дружини як доповнення до чоловіка, певний його атрибут і статус: «Бачать жінку лиш дома і на забаві, то й уважають іiі потрібною лиш для домашньої вигоди або для хвилевої розривки» [4, с. 315]. «Аристократкам, крім невеликих елементарних відомостей, показалася потрібною спеціальна наука чужих язиків як задля частих подорожей, так i для космополітичної конверзації» [4, с. 308]. А ця верства жіночого населення, «маючи доволі вільного часу, <...> маючи за що набувати книжки» [4, с. 308], не мала культурно-світоглядного, ментально сформованого бажання удосконалювати себе 3 метою як особистого, так загальнолюдського національного поступу. «Така-то жінка, з такими економічними засобами сталася взірцем для 
цілої маси наших жінок, котрі замість подібних засобів мали тільки подібні претензії і на їх підставі хотіли попасти в “інтелігенцію”» [4, с. 308], висновувала Н. Кобринська.

Найбільш складною була ситуація представниць «середньої верстви». Як i Е. Ожешко, українська письменниця, вважала, що приреченість таких жінок закладена у вихованні та певних суспільних звичаях. Вони фізично не здатні до праці, бо змалку ця ланка не є пріоритетною, інтелектуально і фахово не готові надавати свої послуги, бо не мають можливості (через традицію, стереотипну пануючу мораль, гендерну нерівність) здобувати грунтовні знання. Їх «призначення» від народження - вийти заміж за чоловіка, який у подальшому має стати матеріальним опікуном і доброю партією для позитивної рецепції дівчини у суспільстві. Галя $з$ оповідання «Задля кусника хліба» мріє про шлюб, який допоможе покласти край соціальним негараздам: «Приймлена 3 ласки до його родини, тепер вона вже по праву буде належати до нього, перестане бути бідною сиротою, буде мати таке саме становисько і поважання у людей, яке мати буде іi чоловік» [4, с. 37]. За таких умов жінка часто віддавала перевагу меркантильним важелям, жертвуючи коханням і природною пристрастю. Галя повірила й переконала себе, що вона може створити гармонійні стосунки, необтяжені лише прагматичним розрахунками: «Роман <...> не був гарний; але для Галі не було тоді кращого мужчини на світі. 3 ним лучилися для неї становисько, удержання і симпатія, - словом, все, що лиш могла вимагати» [4, c. 37]. Однак дівоча проекція майбутнього зазнала фіаско і вона, переможена долею, погоджується на «кусник сухого хліба» [4, с. 52] (заміжжя з учителем Антоном), щоб не «лишитися старою дівчиною», не «бути предметом злосливих уваг і насмішок», не «терпіти пониження» і не «услугувати ціле життя своякам». Учинок Галі - це єдино можливий шанс уникнути пересудів та поневірянь. У вже немолодої попівни, що «все-таки рахувала себе в думці до вищих товариських кружків» [4, с. 34-35] немає альтернативи, щоб позмагатися 3 обставинами, немає фаху і свідомості утилітарного життєвого шляху. Цікавим $є$ факт, що першодрук цього оповідання мав інший фінал: «моральну науку <...> на тему потреби вищої освіти для жінок з економічного становища» [2, с. 11]. Таким чином своєму першому художньому творі Н. Кобринська зосередила увагу на питаннях, які відстоювала протягом життя: відповідний рівень знань це - потужна зброя у боротьбі жінки за такі «блага» як самостійність, фінансова незалежність, рівноправність в інтелектуально-культурній і суспільно-політичній площинах.

У наступному творі «Дух часу» відбувається еволюція образу дівчини 3 династії попівн. Усупереч настановам та сподіванням пані Шумінської їі внучка бунтує проти традиційної ролі і хоче «учитися, аби мати свій власний хліб» [4, c. 127]. Дівчинка висловила своє бажання несміло, «з трудом», проте іiі чітка позиція сформована вже 3 юних років, засвідчила, що вона $є$ представницею іншої генерації, яка наважується ламати традиційні норми усталеного світогляду - суперечить волі старших, не піддається сугестивному впливові найближчого оточення та родинного звичаю, проектує перспективу майбутнього крізь 
призму нових тенденцій: «Надармо мати бігає берегом і кличе роздираючим голосом. Молоде покоління не оглядається і не чує ії поклику» [4, с. 128].

Таким чином, українська письменниця представила власну модель емансипаційного руху, що передбачала активну участь представниць «слабкої статі» в «глобальних цивілізаційних процесах та національно-духовній історії» [8, с. 188], формував образ жінки-інтелектуалки, громадської активістки, людини, яка може форсувати відродження державності, інкарнувати націотворчі процеси, європеїзувати суспільство і жіноцтво зокрема.

Отже, лобіювання принципів рівноправності у своїх національних площинах польська та українська художниці слова здійснювали через потужну вербальну експлікацію гендерної паритетності (публіцистичні праці, художні твори, автонаратив, особистий епістолярій) та створення інституційних осередків («Товариства руських женщин» у Станіславові; друкарні та нелегальної школи для жінок в Гродно). Емансипаційні вектори ідейних переконань Е. Ожешко та Н. Кобринської були схожими в декларуванні таких постулатів, як рівність статей на різних рівнях: соціальному, інтелектуальному, національному.

\section{ЛІТЕРАТУРА}

1. Ciechomska M. Od matriarchatu do feminizmu. Poznań, 1996. $334 \mathrm{~s}$.

2. Грушевський M. Наталія Кобринська URL: http://shron2.chtyvo.org.ua/Hrushevskyi/Nataliia Kobrynska.pdf (дата звернення: 05.11.2018).

3. Jeske-Choiński T. Nowoczesna kobieta. Warszawa, 1917. $64 \mathrm{~s} . \quad$ URL: https://polona.pl/item/nowoczesna-kobieta,MTA4OTE3NzU/39/\#info:metadata (дата звернення: 05.11.2018).

4. Кобринська Н. Вибрані твори. Київ : Дніпро, 1980. 446 с.

5. Magnone L. Marta. Czterdzieści i cztery. Figury literackie. Nowy kanon. Warszawa : Wydawnictwo IBL PAN, 2016. S. 413-429. URL: http://www.academia.edu/30898526/Lena_Magnone_Marta_w_czterdzie\%C5\%9Bci_i_cztery._Fig ury_literackie. Nowy_kanon_red. M. Ruda\%C5\%9B-Grodzka_B. Smole\%C5\%84_K. Nadana-

Soko\%C5\%820wska_A._Mrozik_K._Czeczot_A._Nasi\%C5\%820wska_E._SerafinPrusator_A._Wr\%C3\%B3bel_Warszawa_2016_s. 413_429_ (дата звернення: 05.11.2018).

6. Orzeszkowa E. Kilka słów o kobietach. Publicystyka okresu pozytyzwizmu 1860-1900. Warszawa : Wydawnictwo IBL PAN, 2002. $271 \mathrm{~s}$.

7. Orzeszkowa E. «Marta». Pisma w XXX t. Warszawa : Nakład Gebethnera i Wolffa, 1937. T. III. S. 5-243.

8. Швець А. Жінка з хистом Аріадни. Життєвий світ Наталії Кобринської в генераційному, світоглядному і творчому вимірах. Львів : Інститут Івана Франка НАН України, 2018. 752 с.

9. Stankiewicz-Kopeć M. Poglądy Klementyny z Tańskich Hoffmanowej 1978-1845 w refleksji uczenic. Zarys zagadnienia. Studia Paedagogica Ignatiana, 2016. T. 19, No. 3. S. 99-121. URL: http://apcz.umk.pl/czasopisma/index.php/SPI/article/view/SPI.2016.3.005 (дата звернення: 05.11.2018).

\section{REFERENCES}

1. Ciechomska, M. (1996), From matriarchy to feminism [Od matriarchatu do feminizmu], Poznań, 334 p. (in Polish).

2. Hrushevskyi, M. (1899), "Nataliia Kobrynska" ["Nataliia Kobrynska"], available at: http://shron2.chtyvo.org.ua/Hrushevskyi/Nataliia Kobrynska.pdf (in Ukrainian).

3. Jeske-Choinski, T. (1917), Modern woman [Nowoczesna kobieta], Warszawa, 1917. 64 p., available at: https://polona.pl/item/nowoczesna-kobieta,MTA4OTE3NzU/39/\#info:metadata (in Polish). 
4. Kobrynska, N. (1980), Selected Works [Vybrani tvory]. Dnipro, Kyiv, 446 p. (in Ukrainian).

5. Magnone, L. (2016), "Marta". Forty-four. Literary figures. New canon ["Marta". Czterdzieści i cztery. Figury literackie], Wydawnictwo IBL PAN, Warszawa, pp. 413-429, available at: http://www.academia.edu/30898526/Lena Magnone Marta w czterdzie\%C5\%9Bci i cztery. Fig ury_literackie._Nowy_kanon_red._M. Ruda\%C5\%9B-Grodzka_B._Smole\%C5\%84_K. NadanaSoko\%C5\%82owska_A._Mrozik_K._Czeczot_A._Nasi\%C5\%82owska_E._SerafinPrusator_A._Wr\%C3\%B3bel_Warszawa_2016_s.4113_429_(in Polish).

6. Orzeszkowa, E. (2002), Few words on women. Journalism of the period of Positivism of 18601900 [Kilka słów o kobietach. Publicystyka okresu pozytyzwizmu 1860-1900], Wydawnictwo IBL PAN, Warszawa, 271 p. (in Polish).

7. Orzeszkowa, E. (1937), "Marta", Letters in 30 vols. Vol. 3 ["Marta", Pisma w XXX t. T. 3], Nakład Gebethnera i Wolffa, Warszawa, pp. 5-243. (in Polish).

8. Shvets, A. (2018), Woman with Ariadne's strength. Life world of Natalia Kobrynska in the generation, ideological and creative dimensions [Zhinka z khystom Ariadny. Zhyttievyi svit Natalii Kobrynskoi v heneratsiinomu, svitohliadnomu i tvorchomu vymirakh], Ivan Franko Institute of the National Academy of Sciences of Ukraine, Lviv, 752 p. (in Ukrainian).

9. Stankiewicz-Kopeć, M. (2016), “Clementine's views of the Tahan Hoffman 1978-1845 in the reflections of the students. Review of the issue" [Poglądy Klementyny z Tańskich Hoffmanowej 1978-1845 w refleksji uczenic. Zarys zagadnienia], Studia Paedagogica Ignatiana, Vol 19, No. 3, pp. 99-121. URL: http://apcz.umk.pl/czasopisma/index.php/SPI/article/view/SPI.2016.3.005 (in Polish).

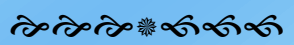

